Journal of Indonesian Tropical Fisheries

ISSN 26554461

Vol. 2, No 1, Juli 2019

Hal 32-42

\title{
EFEKTIFITAS PAKAN DARI BUNGKIL KELAPA SAWIT TERHADAP SINTASAN DAN PERTUMBUHAN IKAN NILA (Oreochromis niloticus)
}

\author{
Effectiveness Of Feed From Palm Oil Dregs To Survival And Growth Of Nila Fish \\ (Oreochromis niloticus) \\ Oleh: \\ St. Hadijah ${ }^{1)}$, Jayadi' ${ }^{2}$, Harlina ${ }^{3)}$, Isya Nurkhaliza ${ }^{4)}$ \\ 1), 2), 3) PS Budidaya Perairan FPIK UMI
}

Korespondensi: dija.gowa@yahoo.co.id

Diterima: tanggal 2 Januari 2019; Disetujui 31 April 2019

ABSTRACT

Tilapia (Oreochromis niloticus) including the Cichlidae family from Africa. Measuring 200 400 grams and omnivorous, it can consume vegetable and animal feed. Palm oil waste has a high enough protein so that it can be used as a source of vegetable protein in fish feed. This study aims to determine the effectiveness of palm oil waste feed on the survival rate, growth and feed conversion of tilapia. This study used a Completely Randomized Design (CRD) with the number of treatments 3 namely $A=$ Palm Oil Dregs (POD) plus fine bran, $B=P O D$ plus fish meal, $C=P O D$ plus soy flour; with 3 replications. The parameters observed were survival, growth and Feed Convertion Rate (FCR). Stocking density for each tilapia 10 individuals / container. The results showed the survival of tilapia in treatments $A$ and B gave the same results (86.66\%) and treatment $C(80 \%)$. The results of analysis of variance showed that the treatment did not significantly affect the survival of tilapia. The growth parameters, both in absolute growth and growth rates of tilapia during the study showed that the treatment had a significant effect on the growth of tilapia and the best treatment was treatment $B$, while treatments $A$ and $C$ were not significantly different. The FCR obtained was treatment A (1.27), B (1.18) and $C$ (1.16). The results of variance analysis showed that the treatment had no significant effect on the tilapia FCR.

Keywords : Palm Oil Dregs, Survival, the growth, FCR, Tilapia.

\begin{abstract}
ABSTRAK
Ikan nila (Oreochromisniloticus) termasuk famili Cichlidae berasal dari Afrika. Berukuran 200-400 gram dan bersifat omnivora sehingga bisa mengkonsumsi pakan nabati dan hewani.Limbah kelapa sawitmemiliki protein yang cukup tinggi sehingga dapat digunakan sebagai sumber protein nabati pada pakan ikan. Penelitian ini bertujuan mengetahui efektifitas pakan limbah kelapa sawit terhadap tingkat kelangsunganhidup, pertumbuhan dan konversi pakan ikan nila. Penelitian ini

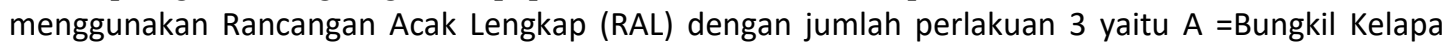
Sawit (BKS) ditambah dedak halus, B =BKS ditambah tepung ikan, C=BKS ditambah tepung kedelai; dengan 3 kali ulangan. Parameter yang diamati adalah sintasan, pertumbuhan dan Feed Convertion Rate(FCR).Padat tebar setiap wadah pemeliharaanikan nila 10 ekor/wadah. Hasil penelitian menunjukkan Sintasan ikan nila perlakuan A dan B memberikan hasil sama $(86.66 \%)$ dan perlakuan C (80\%). Hasil analisis sidik ragam menunjukkan perlakuan tidak berpengaruh nyata terhadap sintasan ikan nila. Parameter pertumbuhan, baik pada pertumbuhan mutlak maupun Laju pertumbuhan ikan nila selama penelitian menunjukkan bahwa perlakuan berpengaruh nyata terhadap pertumbuhan ikan Nila dan perlakuan yang terbaik adalah perlakuan $B$, sedangkan perlakuan $A$ dan $C$ tidak berbeda nyata. FCR yang diperoleh yaitu perlakuan A $(1,27)$, B $(1,18)$ dan $C(1,16)$. Hasil analisis sidik ragam menunjukkan bahwa perlakuan tidak berpengaruh nyata terhadap FCR ikan nila.
\end{abstract}

Kata Kunci : Bungkil Kelapa Sawit; Sintasan; Pertumbuhan; FCR; Ikan Nila. 
PENDAHULUAN

Ikan nilamerupakan ikan air tawar yang di introduksi dari Afrika. Termasuk dalam famili Cichlidae dengan nama ilmiah Oreochromisniloticus yang dalam bahasa Inggris dikenal sebagai Nile Tilapia. Ikan ini merupakan spesies ikan yang berukuran besar antara 200-400 gram dan bersifat omnivora sehingga bisa mengkonsumsi makanan berupa hewan dan tumbuhan.Ikan Nila mempunyai prospek cerah, pertumbuhannya relatif cepat dan dapat beradaptasi dengan baik terhadap lingkungannya sehingga sangat mudah untuk dibudidayakan (Arie, 2003).

Limbah kelapa sawit merupakan salah satu sumber protein nabati berpotensi dimanfaatkan sebagai pakan ikan yang diharapkan dapat meningkatkan nilai gizi pakan. Salah satu Limbah kelapa sawit yang dapat digunakan sebagai pakan ikan adalah Bungkil Kelapa Sawit (BKS). Namun, BKS ini mempunyai faktorpembatas, yaitu kandungan seratnya cukup tinggi. BKSdapat digunakan sebagai sumberprotein nabati karena memiliki kandungan asam amino esensial yang cukup lengkap. Keseimbangan kalsium dan fosfornya cukup baik(Lubis, 1993)dalam (Farida dkk., 2016) . Ketaren, (1986) menjelaskan bungkil kelapa sawit mempunyai nilai nutrisi yang lebih tinggi dibanding limbah lainnya dengan kandungan protein kasar $15 \%$ dan energi kasar $4.230 \mathrm{kkal} / \mathrm{kg}$, sehingga dapat berperan sebagai pakan penguat (konsentrat).

Penggunaan limbah kelapa sawit telah banyak dilakukan pada ternak namun belum banyak dimanfaatkan untuk pakan ikan.Masalah utama dalam budidaya ikan adalah penggunaan pakan.Hampir $50 \% \quad-\quad 70 \%$ ongkos produksi dihabiskan dalam biaya pakan ikan. Penelitian ini mencoba memanfaatkan limbah kelapa sawit yang mempunyai nilai nutrisi yang masih cukup tinggi untuk menekan ongkos produksi dalam budidaya ikan Nila

Peneitian ini akan menguji penggunaan bungkil kelapa sawit sebagai pakan ikan dengan menambahkan bahan yang banyak 
tersedia dan memiliki kandungan nutrisi yang cukup untuk pertumbuhan ikan nila seperti bahan dengan campuran dedak halus, tepung ikan dan tepung kedelai. Penelitian ini bertujuan mengetahui efektifitas pakan limbah kelapa sawit terhadap tingkat kelangsunganhidup, pertumbuhan dan konversi pakan ikan nila.

\section{METODE PENELITIAN}

Penelitian ini dilaksanakan selama dua bulan terhitung mulai April sampai Juni 2018 di Laboratorium Basah Akuakultur Politeknik Pertanian Negeri Pangkep Kecamatan Mandalle Kabupaten Pangkep Provinsi Sulawesi Selatan.

Alat yang digunakan adalah akuarium, seser, baskom, termometer, pH meter, DO meter, timbangan digital, penggaris, kamera, alat tulis. Bahan yang digunakan adalah ikan nila berukuran $8 \mathrm{~cm}$ dengan berat rata-rata $11,65 \mathrm{~cm}$, air tawar, dan pakan pellet yang diproduksi sendiri. Wadah yang digunakan adalah akuarium berukuran $60 \times 40 \times 40 \mathrm{~cm}$, diisi air bersih dengan ketinggian air $20 \mathrm{~cm}$ pada setiap akuarium. Setiap akuarium diberikan label perlakuan dan ulangan. Padat penebaran ikan pada wadah sebanyak 10 Ekor. Dosis pemberian pakan $5 \%$ (Zulkhasyni, dkk; 2017), frekuensi pemberian pakan dilakukan 3 kali sehari, pagi, siang dan sore. Parameter kualitas air yang diamati adalah suhu, oksigen terlarut dan $\mathrm{pH}$ air. Pakan yang diberikan pada ikan nila adalah jenis pakan pellet berbahan dasar bungkil kelapa sawit dengan campuran yang berbeda sesuai dengan perlakuan yang diberikan. Penelitian ini menggunakan Rancangan Acak Lengkap (RAL) dengan jumlah perlakuan 3 yaitu $\mathrm{A}=$ Bungkil Kelapa Sawit (BKS) ditambah dedak halus, $\mathrm{B}=\mathrm{BKS}$ ditambah tepung ikan, $\mathrm{C}=\mathrm{BKS}$ ditambah tepung kedelai; dengan 3 kali ulangan.

Parameter yang digunakan dalam penelitian ini sebagai berikut :

\section{a. Sintasan (SR)}

Sintasan ikan nila pada setiap perlakuan dihitung dengan rumus Effendie (1997) sebagai berikut:

$$
\mathrm{SR}=\frac{\mathrm{Nt}}{\mathrm{No}} \times 100 \%
$$


Dimana :

$\mathrm{SR}=$ Sintasan/ persentase hidup (\%)

$\mathrm{Nt}=$ Jumlah ikan yang hidup pada akhir penelitian (ekor)

No $=$ Jumlah ikan yang hidup pada awal penelitian (ekor)

\section{b. Pertumbuhan}

Pertumbuhan ikan dalam penelitian ini dinyatakan dalam berat ikan setiap harinya selama pemeliharaan berdasarkan rumus Effendie (1997) sebagai berikut:

\section{Pertumbuhan Mutlak}

$$
\mathrm{W}=\mathrm{Wt}-\mathrm{Wo}
$$

Dimana :

$\mathrm{W}=$ Pertumbuhan mutlak (gram)

$\mathrm{Wt}=$ Bobot rata-rata ikan selama

pemeliharaan waktu (gram)

$\mathrm{Wo}_{\mathrm{O}}=$ Bobot awal rata-rata ikan pada awal penebaran

(gram)Pertumbuhan Berat

Harian

$A D G=$

$$
\mathrm{F}=\text { Jumlah pakan yang }
$$
dikonsumsi.

Data yang diperoleh dalam penelitian ini di analisis menggunakan sidik ragam (ANOVA) dan uji lanjut
$\mathrm{H}$

Dimana :

$$
\begin{aligned}
\mathrm{ADG}= & \text { Pertumbuhan berat harian } \\
& (\text { gram } / \text { hari }) \\
\mathrm{Wt}= & \text { Bobot rata-rata ikan selama } \\
& \text { pemeliharaan waktu (gram) } \\
\mathrm{Wo}= & \text { Bobot awal rata-rata ikan } \\
& \text { pada awal penebaran } \\
& (\text { gram }) \\
\mathrm{H}= & \text { Lama pemeliharaan (hari) }
\end{aligned}
$$

\section{c. Feed Convertion Rasio (FCR)}

Konversi pakan dihitung dengan rumus Djajasewaka (1985) dalam Rina dan Elrifadah (2015), yaitu:

F

$\mathrm{FCR}=$

$$
(\mathrm{Wt}+\mathrm{D})-\mathrm{Wo}
$$

Dimana :

FCR $=$ Feed Convertion Ratio.

Wo $=$ Bobot hewan uji pada awal penelitian .

$\mathrm{Wt}=$ Bobot hewan uji pada akhir penelitian .

$\mathrm{D}=$ Jumlah ikan yang mati tukey guna mengetahuipengaruh perlakuan, menggunakan SPSS versi 22 For Windows. Sedangkan untuk penyajian grafik dan tabulasi data menggunakan Mikrosoft Excel 2007. 
HASIL DAN PEMBAHASAN

\section{Sintasan}

Sintasan ikan dipengaruhi oleh berbagai faktor yang meliputi kondisi lingkungan, ketersedian pakan, persaingan antar orgaisme dan kondisi fisik organisme serta kualitas air.Faktorfaktor tersebut harus tetap dijaga agar sintasan ikan yang dibudidaya tetap tinggi.Sintasan rata-rata ikan nila selama penelitian dapat dilihat pada Gambar 1.

Gambar 1. Sintasan ikan nila selama penelitian

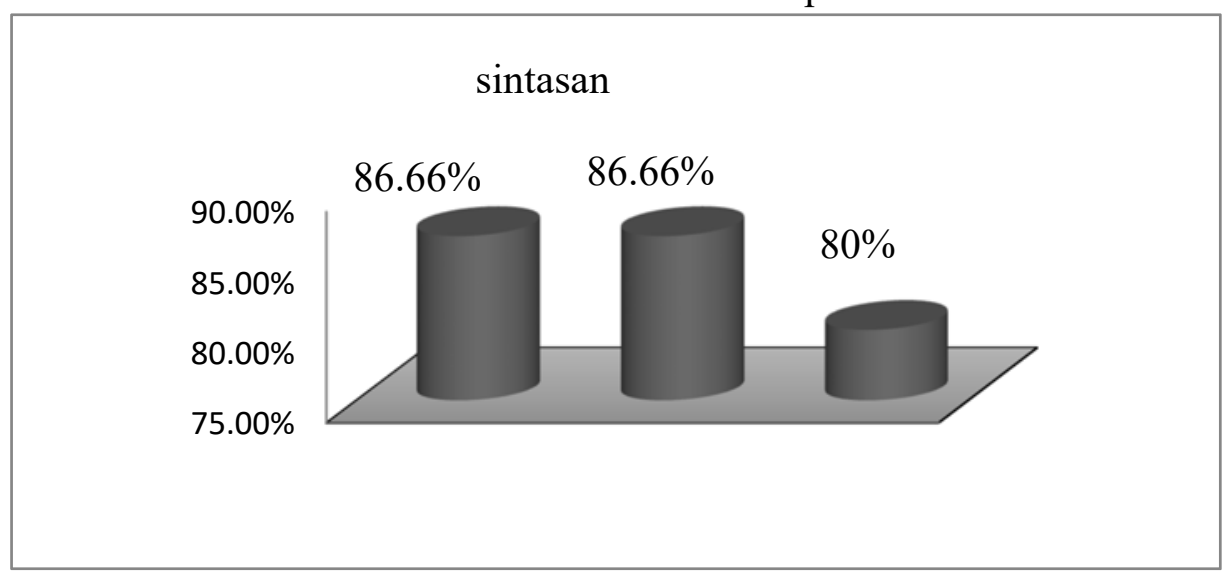

Dari Gambar 1 dapat diketahui bahwa sintasan ikan nila selama penelitian memberikan hasil cukup tinggi dengan nilai sintasan tertinggi 86,66\%. Dari uji analisis statistik sidikragam one-way anova pada taraf 95\% didapatkan hasil bahwaperlakuan tidak berpengaruh nyata terhadapsintasan ikan uji.

Sintasan tertinggi hingga 86,66\% pada penelitian ini masih lebih rendah dibanding hasil penelitian Pamungkas (2013) yang memperoleh sintasan ikan patin hingga 97\%. Hal ini karena
Pamungkas (2013) melakukan perlakuan tambahan pada tepung BKS yang diujikan dengan caramenghidrolisis BKS dengan enzim rumen Sapi. Sehingga diperoleh uji patabilitas tepung bungkil kelapa sawit yang dihidrolisis dengan enzim rumen berpengaruh terhadap tingkat kelangsungan hidup pada ikan patin. Kematian ikan uji pada perlakuan A,B, dan C terjadi pada pengukuran ikan minggu pertama akibat dari kematian tersebut karena mengalami stress pada awal pemeliharaan dan lingkungan yang 
berubah, pemindahan secara mendadak seiring dengan berubahnya waktu. dapat menyebabkan ikan tersebut stress bahkan mati (Kordi, 2010).

\section{Pertumbuhan}

Perlakuan pemberian pakan pada ikan uji mendapatkan hasil pertumbuhan Menurut Effendi (1997), pertumbuhan adalah perubahan ikan 2.

dalam berat, ukuran, maupun volume

\section{Pertumbuhan Mutlak}

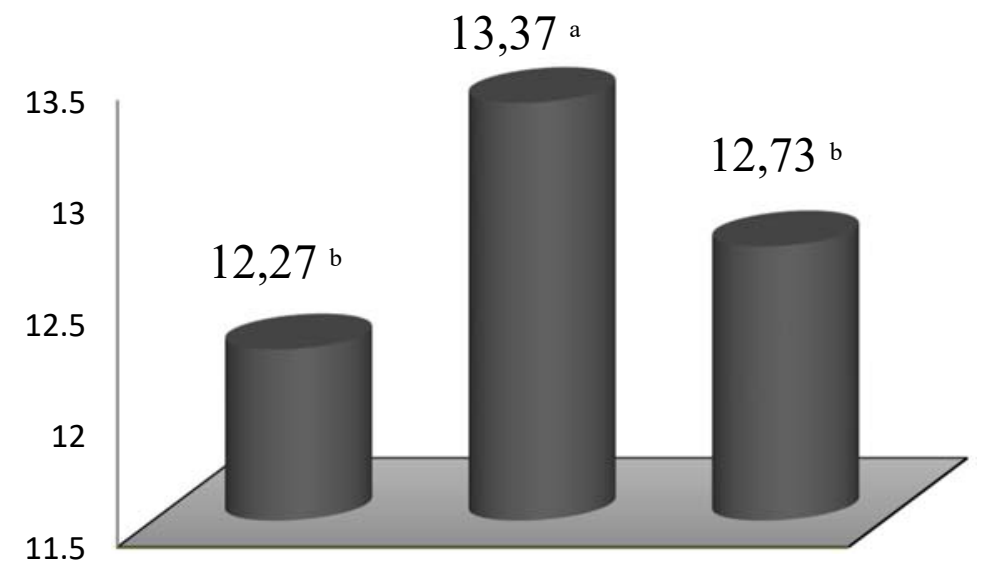

Gambar 2. Pertumbuhan mutlak ikan uji

Ket : Angka yang diikuti huruf yang berbeda menunjukkan perlakuan berbeda nyata (taraf 95\%). 
Gambar dua menunjukkan adanya perbedaan pertumbuhan antar perlakuan yang diujikan.Hasil analisis sidik ragam menunjukkan adanya pengaruh perlakuan pada penelitian ini pada taraf 95\%.Hasil Uji lanjut Tukey menunjukkan adanya perbedaan pertumbuhan mutlak yang nyata pada masing-masing perlakuan.Berat ikan tertinggi yang diperoleh pada akhir penelitian sebesar 13,37 grpada perlakuan $\mathrm{B}$ menunjukkan bahwa ikan Nila yang diberi BKS yang ditambah dengan tepung ikan lebih baik pertumbuhannya disbanding dengan kedua perlakuan lainnya.Pertumbuhan pakan perlakuan $B$ terbaik karena perlakuan ini BKS dicampur dengan tepung Ikan yang menjadikan jumlah nutrisinya cukup sehingga mampumemberikan energi untuk kegiatan metabolisme tubuh ikan nila, dan juga mampu memenuhi kebutuhan ikannila untuk tumbuh (Aljabbar, 2005; Yolanda dkk; 2013).

\section{Laju Pertumbuhan}

Laju pertumbuhan harian yang diperoleh pada penelitian ini disajikan pada Tabel 1.
Tabel 1 . Laju pertumbuhan berat harian ikan uji setiap perlakuan

\begin{tabular}{cc}
\hline Perlakuan & $\begin{array}{c}\text { Laju pertumbuhan } \\
(\mathrm{gr} / \mathrm{hari})\end{array}$ \\
\hline A & $0,20^{\mathrm{a}}$ \\
B & $0,22^{\mathrm{b}}$ \\
C & $0,21^{\mathrm{a}}$ \\
\hline
\end{tabular}

Ket : Angka yang diikuti huruf yang berbeda menunjukkan perlakuan berbeda nyata (taraf 95\%)

Tabel 1 yang tersaji menunjukkan adanya perbedaan laju pertumbuhan ikan uji dengan setiap perlakuan yaitu A (0,20 gr/hari), B (0,22 $\mathrm{gr} /$ hari $)$ dan $\mathrm{C} \quad(0,21 \mathrm{gr} / \mathrm{hari})$. Berdasarkan analisis sidik ragam taraf $95 \%$ diperoleh hasil analisis perlakuan berpengaruh nyata terhadap laju pertumbuhan ikan uji. Hasil uji lanjut tukey pada masing-masing perlakuan menunjukkan bahwa perlakuan B berbeda nyata dengan perlakuan A dan C, pelakuan A tidak berbeda nyata dengan perlakuan $\mathrm{C}$.

Laju pertumbuhan harian ikan nila yang diperoleh pada penelitian ini msih lebih rendah dibandingkan dengan penelitian Farida dkk., (2016) dengan percobaan subtitusi fermentasi bungkil 
kelapa sawit dalam pakan buatan terhadap pertumbuhan ikan gurami, dengan perolehan hasil laju pertumbuhan harian 1,502 gr/hari. Penggunaan perlakuan tambahan pada BKS berupa fermentasi ternyata dapat meningkatkan laju pertumbuhan harian pada ikan. Hal ini karena fermentasi dapat meningkatkan kadar protein pada pakan BKS. Pada penelitian ini BKS yang digunakan tidak diberi perlakuan lain dan ditambahkan saja dengan tepung ikan sehingga kandungan proteinnya kurang optimal.

\section{FCR}

Konversi pakan merupakan perbandingan antara jumlah pakanyang diberikan dengan jumlah berat ikan yangdihasilkan. Semakin kecil nilai konversi pakanberarti tingkat pemanfaatan pakan lebih efisiensebaliknya apabila konversi pakan besar, maka tingkat pemanfaatan pakan kurang efisien. Dari hasil FCR selama penelitian dapat diliat pada Tabel 2.
Tabel 2. Konversi pakan ikan nila selama penelitian

\begin{tabular}{cc}
\hline Perlakuan & FCR \\
\hline A & $1,27^{\mathrm{a}}$ \\
B & $1,18^{\mathrm{a}}$ \\
C & $1,16^{\mathrm{a}}$ \\
\hline
\end{tabular}

Ket: Angka-angka yang diikuti huruf yang sama menunjukkan perlakuan tidak bebeda nyata (taraf $95 \%$ )

Dari uji analisis statistik sidikragam one-way ANOVA pada taraf 95\% diperoleh hasil bahwaperlakuan yang diujikan pada penelian ini tidak berpengaruh nyata terhadap FCR ikan uji.

Dari hasil penelitian Iskandar dan Elrifadah (2015) pada percobaan pertumbuhan dan efesiensi pakan ikan nila yang diberi pakan buatan berbasis kiambang mendapatkan hasil yang terendah yaitu 1,11 dan tertinggi 1,12. Hal ini menunjukkan bahwa pemberian pakan BKS memberikan hasil yang cukup baik. Konversi pakan yang diperoleh menunjukkan kualitas pakan BKS pada penelitian ini cukup baik. 


\section{Kualitas Air}

Kualitas air merupakan salah satu faktor eksternal yang dapat mempengaruhi pertumbuhan ikan Nila. Parameter kualitas air yang diukur selama penelitian dapat dilihat pada Tabel 3.

Tabel 3. Parameter kualitas air selama penelitian

\begin{tabular}{ccc}
\hline No & Parameter & $\begin{array}{c}\text { kisaran } \\
\text { pengamatan }\end{array}$ \\
\hline 1 & suhu & $26{ }^{0} \mathrm{C}-27{ }^{0} \mathrm{C}$ \\
2 & $\mathrm{pH}$ & $6-7$ \\
3 & $\mathrm{DO}$ & $5,04-7,17 \mathrm{mg} / 1$ \\
\hline
\end{tabular}

Pertumbuhan ikan yang baik memerlukan temperatur optimum $25^{\circ} \mathrm{C}$ $-29^{\circ} \mathrm{C}$ dan perubahan suhu pada siang hari dan malam hari tidak lebih $5{ }^{0} \mathrm{C}$ (Cahyono, 2000), sehingga dengan kisaran suhu $26{ }^{0} \mathrm{C}-27{ }^{0} \mathrm{C}$ dapat menunjang pertumbuhan ikan nila selama penelitian.Kisaran $\mathrm{pH}$ yang baik untuk budidaya ikan nila adalah 5 - 9. Nilai $\mathrm{pH}$ 7,0 -8,5 adalah nilai $\mathrm{pH}$ yang ideal (Effendi H.; 2003). Tingkat keasaman media pemeliharaan berkisar antara 6 - 7 yang masih dalam kisaran normal untuk ikan dapat tumbuh dan berkembang baikOksigen terlarut dalam air dapat mempengaruhi aktivitas ikan nila dan berpengaruh pada metabolisme dalam tubuh ikan, oksigen terlarut selama penelitian berkisar antara 5,04 7,17 mg/L. Hal ini di perkuat oleh Kordi (2009), nila mampu bertahan hidup dalam kandungan oksigen yang rendah hingga $2 \mathrm{mg} / \mathrm{l}$, tetapi nilai kisaran oksigen yang baik untuk budidaya antara 5-7 mg/l.Kecilnya nilai oksigen terlarut dalam air kemungkinan disebabkan oleh proses aerasi yang kurang tepat karena besar kecilnya aerasi akan berpengaruh terhadap banyak sedikitnya oksigen dalam air (Ardita dkk., 2015)

Berdasarkan hasil tersebut terlihat bahwa ikan nila hidup pada kondisi perairan yang normal. Keadaan yang hampir mirip dengan habitat sebenarnya ini memungkinkan untuk ikan nila dapat melakukan pertumbuhan dengan baik.

\section{KESIMPULAN DAN SARAN}

\section{Kesimpulan}

Kesimpulan yang diperoleh pada penelitian ini adalah :

1. Pemberian pakan Bungkil kelapa sawit tidak berpengaruh 
nyata terhadap sintasan ikan Nila.

2. Pemberian pakan Bungkil kelapa sawit berpengaruh nyata terhadap pertumbuhan. Perlakuan yang terbaik adalah perlakuan $\mathrm{B}$ yang menghasilkan pertumbuhan mutlak tertinggi yaiti 13,37 gr.

3. FCR yang diperoleh cukup rendah yaitu kisaran 1,16 hingga 1,27 dan hasil analisis menunujukkan tidak ada pengaruh perlakuan terhadap FCR yang diperoleh.

4. Parameter kualitas air yang diperoleh pada penelitian ini masih dalam kisaran yang layak.untuk keberlangsungan budidaya ikan Nila

\section{Saran}

Perlu dilakukan tindakan tambahan berupa fermentasi bungkin kelapa sawit agar dapat ,meningkatkan kadar protein pakan yang diproduksi. Dengan demikian akanmeningkatkan produksi ikan nila yang dibudidaya. Peningkatan kesejahteraan masyarakat pembudidaya juga dapat terlaksana karena dapat menghemat biaya produksi dengan memanfaatkan limbah yang ada disekitar daerah para pembudiaya.

\section{UCAPAN TERIMA KASIH}

Tulisan ini merupakan bagian dari penelitian dasar unggulan perguruan tinggi dan penulis mengucapkan terima kasih kepada Direktorat Riset dan Pengabdian Masyarakat, Direktorat Jenderal Penguatan Riset dan Pengembangan Kemnterian Riset, Teknologi dan Pendidikan Tinggi yang telah membiayai penelitian ini.

\section{DAFTAR PUSTAKA}

Afifah R. 2006. Pemanfaatan Bungkil Kelapa Sawit dalam Pakan Juvenil Ikan Patin Jambal (Pangasius djambal) [Skripsi]. Bogor: Fakultas Perikanan dan Ilmu Kelautan, Institut Perikanan Bogor. 29 hal.

Aljabbar, I. 2005. Penggunaan Tepung Bungkil Kedelai sebagai Pengganti Tepung Ikan dalam Pakan Juvenil Kerapu Bebek. (Skripsi).Fakultas Perikanan dan Ilmu Kelautan, IPB. Bogor. $25 \mathrm{hlm}$.

Ardita. N. Budiharjo. A. Sari, S.L.A. 2015 "Pertumbuhan dan rasio konversi pakan ikan nila (Oreochromis niloticus) dengan penambahan probiotik. Jurnal Bioteknologi. 12(1) :1621ISSN : $0216-6887$. 
Arie, U.2003. Pembenihan dan Pembesaran Ikan Nila Gift. Jakarta. Penebar Swadaya. Jakarta.

Cahyono, B. 2000. Budidaya Ikan Air Tawar Ikan Gurami, Ikan Nila dan Ikan Mas Kanisius. Yogyakarta.

Effendi H. 2003. Telaah Kualitas Air Bagi Pengelolaan Sumber Daya dan Lingkungan Perairan. Kanisius. Yogyakarta.

Effendi. 1997. Biologi Ikan . Yayasan Pustaka Purnama. Yogyakarta.

Farida, Raharjo,E.I, Sari. A.M, 2016. Subtitusifermentasi bungkil kelapa sawit dalam pakan buatan terhadap pertumbuhan dan kelangsungan hidup benih ikan gurami (Osphoronemus gouramy). Jurnal Ruaya Vol.4.No.1 ISSN= 25413155https://id.wikipedia.org/wi ki/lkan nila diakses 28 Maret 2018.

Iskandar, R. Dan Elrifadah. 2015. Pertumbuhan dan efesiensi pakan ikan nila (Oreochromis niloticus) yang diberi pakan buatan berbasis kiambang, jurnal penelitian Ziraa'ah Vol 40 No 1.

Ketaren, P.P. 1986. Bungkil inti sawit dan ampas minyak sawit sebagai pakan ternak. Warta Penelitian dan Pengembangan Pertanian 8(4-6): 10-11.

Kordi, M Gufron., 1997. Budidaya Ikan Nila. Dahara Prize. Semarang.

Kordi, Ghufran. H.

2010. Membudidayakan

Niladi Kolam Terpal.

LilyPublisher. Yogyakarta.
Kottelat, M. and A. J. Whitten. 1993. Freshwater Fishes of Western Indonesia and Sulawesi (diterjemahkan oleh Sri Nuriyani Kartikasari dan Soetikno Wirjoatmojo). Periplus Editions (HK) Ltd, Jerman.

Pamungkas, W. 2013. Uji patabilitas tepung bungkil kelapa sawit yang dihidrolisis dengan enzim rumen dan efek terhadap respon pertumbuhan benih ikan patin siam. Berita Biologi 12(3).

Suriansyah. 2014. Pengaruh padat tebar yang berbeda terhadap pertumbuhan ikanNila Gift (Oreochromis niloticus) yang dipelihara dalam baskom plastik[skripsi]. Pangkalan Bun: Program Studi Budidaya Perairan, Fakultas Pertanian, Universitas Antakusuma.

Yolanda, S. Santoso, L. dan Harpeni, E. 2013. Pengaruh subtitusi tepung ikan dengan tepung ikan rucah terhadap pertumbuhan ikan nila gesit (Oreochromis niloticus). EJurnal Rekayasa Dan Teknologi Budidaya Perairan. Vol 1 No 2. ISSN : 2302 3600

Zulkhasyni. Adriyeni. Utami, R. 2017. Pengaruh dosis pakan pellet yang berbeda terhadap pertumbuhan ikan nila merah (Oreochromissp). Jurnal Agroaqua. Vol. 15 No.2, p. $35-42$, dec. 2017. ISSN 25984071. 